\title{
Analysis of the Impact of Exports and Investment on Indonesian Economic Growth
}

\author{
Alfred Leonard, Tanti Novianti, Sri Mulatsih \\ Department of Economics, Faculty of Management Economics, Bogor Agricultural University, Indonesia
}

\begin{abstract}
Article Info

Volume 8, Issue 5

Page Number : 92-101

Publication Issue :

September-October-2021

Article History

Accepted : 10 Sep 2021

Published: 16 Sep 2021

The average share of net exports to Indonesia's economic growth was only $1.01 \%$ in the last 30 years. The contribution and important role of manufacturing industry exports in total national exports ranged from $73.62-80.91 \%$ with an average of $78.30 \%$ in the last 10 years $(2010-2020)$. This study aims to analyze the impact of manufacturing industry exports and investment on economic growth through the export-led growth hypothesis. The results show that there is a long-term relationship between foreign investment, domestic investment, employment, and manufacturing industry exports to GDP. Domestic investment and manufacturing exports have a positive effect on GDP, on the other hand, foreign investment and employment have a negative effect. An indication of the negative influence of FDI in Indonesia is due to the low rate of economic return. In addition, the negative effect of labor absorption is indicated by the unavailability of adequate employment opportunities.
\end{abstract}

Keywords : Manufacturing Industry Exports, Investment, Economic Growth

\section{INTRODUCTION}

In international trade activities, exports are the most important variable for a country. Exports bring in foreign exchange which is useful for creating imports of commodities and raw materials as well as capital goods for export production purposes. Exports and imports are the main components in the identity of the Gross Domestic Product (GDP) and determine the country's economic growth. Higher export growth can directly lead to increased economic growth. Because it contributes to economic growth, the development and diversification of exports will have a major impact on growth (Ferreira and Harison, 2012; Agrawal, 2015).

Economic data shows that the value of exports in Indonesia's GDP since 1990 - 2020 has fluctuated between $17.90-26.45 \%$ with an average of $22.39 \%$. Meanwhile, the import value fluctuated between $16.23-27.63 \%$ with an average of $21.38 \%$ (Bank Indonesia, 2020). According to the value of exports and imports in GDP, the average net export share of Indonesia's economic growth is only $1.01 \%$ in a period of 30 years. The amount of this share is still very small so it needs to be increased. 
The export contribution of the manufacturing industry in total national exports ranges from 73.62 $80.91 \%$ with an average of $78.30 \%$ in the last 10 years (2010 - 2020). Meanwhile, the agriculture, mining and quarrying sectors only contributed $21.70 \%$ (Bank Indonesia, 2020). Thus, the manufacturing industry sector becomes the main component and plays an important role in national exports and as the main sector providing production for export purposes. The Indonesian government focuses on and supports the development of the manufacturing industry in an effort to increase national exports. Through the development of the manufacturing industry, the number of production and value added is increasing so that the potential for export value also increases.

To develop exports requires investment expansion so that export production grows. Just like exports and imports, investment is the dominant variable in the construction and development of production. Through current investment, future production is expected to increase and be fulfilled. An important component of investment is Foreign Direct Investment (FDI) and Domestic Investment (DI). Foreign investment has a potential contribution to economic growth and restructuring (Lindblad, 2015). Domestic investment also plays a role in supporting growth therefore the government needs to encourage the expansion of domestic investment (Faizah, et al. 2019).

In the development of exports and expansion of investment, the availability of labor is very necessary. Indonesia has a large workforce that can be utilized for export development and investment expansion. The extent to which export development followed by investment is successful in absorbing labor requires a more in-depth analysis. Tadjoeddin (2014) states that there are several policies set by the government, namely reducing unemployment which is targeted to reach $5-6 \%$ in 2014. However, in fact decent work is not available so that the target for reducing unemployment is not achieved.
The data presented earlier shows that the share of exports in Indonesia's economic growth is still very small (1.01\% of GDP). This condition encourages the need to analyze the impact of exports on economic growth. Analysis of this has been done by many analysts before, but this study tries to analyze the impact of manufacturing industry exports on economic growth associated with investment, employment as a factor of production through the export-led growth hypothesis.

Studies on the impact of exports were conducted among others by Leichenko (2000) who investigated the causal relationship between exports and economic growth at the country and regional levels in the United States. The results show that exports have a positive impact on economic growth and have twoway causality. A similar analysis was conducted to examine the impact of export performance on the productivity growth of the manufacturing sector in the Singapore economy (Thangavelu and Owyong, 2003). The results show that exports make a significant contribution to industrial productivity growth.

Another analysis to verify the export-led growth hypothesis in the Bangladeshi economy is whether manufacturing exports have become a new export-led growth replacing total exports (Hossain and Karunaratne, 2004). The results show that both total exports and manufactured exports have a positive and statistically significant impact both in the long and short term on economic growth. However, after a separate analysis, it was found that the different results were that manufacturing exports were not dominant in becoming export-led growth in Bangladesh.

Many researchers have also conducted an examination of the impact of investment on Indonesia's economic growth. The analysis conducted by Khaliq and Noy (2007) to examine the impact of 
foreign investment on growth shows that at the aggregate level, FDI has a positive effect on growth but when analyzing across sectors, the results show that sectors have a negative effect. The results of the analysis Suyanto, et al. (2012) is also similar to Khaliq and Noy (2007). The results of another analysis by Aftab and Parikh (2018) for the Indian economy also show that FDI has a significant effect on growth. In addition, the results of the analysis of the impact of domestic investment on Indonesia's economic growth were carried out by Djulius, et al. (2019) shows that domestic investment has a positive effect on economic growth.

To verify the impact of labor absorption on Indonesia's economic growth, the results of the analysis by Van der Eng (2010) show that employment has a positive effect. Based on the results of the analysis of the study above, it will be verified through the results of this study.

\section{THEORETICAL FRAMEWORK}

\subsection{Gross Domestic Product}

Gross Domestic Product (GDP) is the value of all goods and services produced in a country in a certain period of time, generally per year (Mankiw, 2006). Grouping the calculation of Gross Domestic Product (GDP) is carried out using a production approach and an expenditure approach. At the aggregate level, the values from both sides of the approximation must be the same. The measurement of the value of GDP can be made based on current prices called Nominal GDP, and measurements based on constant prices are called Real GDP. GDP shows the level of state income where when divided by the total population it is known as income per capita which shows the level of individual welfare of society.

The calculation of GDP with the expenditure approach is referred to as the identity of the national income item with the formula:
$\mathrm{Y}=\mathrm{C}+\mathrm{I}+\mathrm{G}+\mathrm{NX}$

Information:

$\mathrm{Y}=$ Total demand for domestic output (GDP)

$\mathrm{C}=$ Household consumption

I = Investment expenditure in business and household sectors

$\mathrm{G} \quad=$ Government spending

NX $=$ Net exports or net foreign demand.

On the production side, the output of goods and services in an economy (GDP) depends on the factors of production available in the economy and the ability of the available production function to convert inputs into outputs. In general, the factors of production consist of capital $(\mathrm{K})$ and labor $(\mathrm{L})$, and the production function is written in the following formula (Mankiw, 2006).

$\mathrm{Y}=\mathrm{F}(\mathrm{K}, \mathrm{L})$

Information:

$\mathrm{Y}=$ Revenue (production)

$\mathrm{K} \quad=$ Capital input (capital)

$\mathrm{L}=$ labor input (labor)

The production function shows how much production is achieved in the economy depending on the amount of use of capital and labor inputs. In the long run the amount of capital and labor available in the economy is certain so that the amount of output becomes constant.

\subsection{Export-Led-Growth Model}

The Export-Led-Growth (ELG) hypothesis postulates that export expansion is a key factor in driving longterm economic growth. Theoretically, there are several arguments that support and justify the hypothesis. First, exporting activities are related to demand. The export market abroad has a wide scope and scope, thus opening up opportunities for sustainable export development. If this opportunity is realized, the contribution of export demand in the national income identity will be sustainable (Dreger and Herzer, 2013). 
Second, exporting products abroad generates foreign exchange which opens up opportunities to import production factors that are not available domestically. The main production factors that are generally used for export production include raw and auxiliary materials as well as capital goods. The use of these imported production factors will increase export production which means boosting output growth. Imports of capital goods play a role in increasing domestic capital formation and expanding production capacity. Imports of capital goods from technologically advanced countries can improve domestic technology so that productivity increases and boosts growth.

How the above theoretical argument is analyzed in economics, the following neoclassical production function is used:

$Y_{t}=A_{t} K_{t}^{\alpha} L_{t}^{\beta}$

Information:

Yt = aggregate production of the economy at time $\mathrm{t}$,

At $=$ total factor productivity level

$\mathrm{Kt} \quad=$ capital stock

$\mathrm{Lt} \quad=$ number of workers.

To analyze the impact of manufacturing industry exports affecting economic growth through increased productivity, in this study it is assumed that total factor productivity can be expressed as a function of imports of raw and auxiliary materials (MBBPt), imports of capital goods (MBM), exports of manufacturing industries (XMFt), primary exports (XSPRt), and other exogenous factors:

$$
\begin{aligned}
A_{t} & =f\left(M B B P_{t}, M B M, X M F_{t}, X S P R_{t}\right) \\
& =M B B P_{t}^{\delta} M B M_{t}^{\gamma} X M F_{t}^{\rho} X S P R_{t}^{\vartheta} \ldots .
\end{aligned}
$$

By combining equations (3) and (4) we get:

$Y_{t}=K_{t}^{\alpha} L_{t}^{\beta} M B B P_{t}^{\delta} M B M_{t}^{\gamma} X M F_{t}^{\rho} X S P R_{t}^{\vartheta}$

Information:

Yt = Aggregate production of the economy at time $\mathrm{t}$,

$\mathrm{Kt}$, Lt = Capital stock, and labor, respectively

MBBPt = Import of raw and auxiliary materials

MBMt = Import of capital goods

$\mathrm{XMFt}=$ Manufacturing industry exports

XSPRt = Primary sector exports

$\alpha, \beta, \delta$,

$\gamma, \rho, \vartheta=$ Production elasticity of Kt, Lt, MBBPt,

MBMt, XMFt, and XSPRt, respectively.

Taking the natural logarithm of both sides of equation (5) gives a linear function that can be estimated as:

$\ln Y_{t}=c+\alpha \ln K_{t}+\beta \ln L_{t}+\delta \ln M B B P_{t}+$ $\gamma \ln M B M_{t}+\rho \ln X M F_{t}+\vartheta \ln X S P R_{t}+$

$e_{t} \ldots \ldots \ldots \ldots \ldots . . . . .(6)$

According to equation (6), the adjustment model used in the analysis of this study is:

$\ln D P D B X_{t}=c+\alpha \ln P M A_{t}+\beta \ln P M D N_{t}+$ $\delta \ln T T K_{t}+\gamma \ln X M F_{t}+$

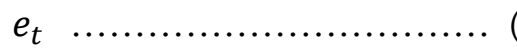

Information:

DPDBXt = Gross Domestic Product without export value at time $t$,

PMAt = Foreign investment at time $\mathrm{t}$,

PMDNt = Domestic investment at time $\mathrm{t}$,

TTPt = Absorption of labor at time $t$,

$\mathrm{XMFt} \quad=$ Exports of manufacturing industry at time $\mathrm{t}$.

\section{METHODOLOGY}

\subsection{Variables, Types and Data Sources}

The variables used in the analysis of this study include Gross Domestic Product (GDP), foreign investment (PMA), domestic investment (PMDN), employment (TTK), and manufacturing industry exports (XMF). The GDP variable is specified as DPDBX, which is the value of GDP after deducting exports. The value of the original GDP is formed by the expenditure values of which come from the value of exports. In this case, if the export data is regressed with GDP directly, a 
positive relationship according to the data value has occurred, therefore the value of GDP needs to be reduced by the value of exports (Dreger and Herzer, 2013).

The data used in this study is the quarterly time series data from 1993 to the first quarter of 2021. According to available data, investment is separated between foreign direct investment (FDI) and domestic investment (DI). Labor data are obtained from the Investment Coordinating Board (BKPM) which reports quarterly data on employment absorption according to foreign investment and domestic investment in Indonesia. Other data were obtained from Bank Indonesia and the Indonesian Central Statistics Agency. The analytical method used in this study is the VECM model using the EVIEWS 10 application.

\subsection{Analysis Method}

\section{Model Vector Error Correction Model (VECM)}

To determine the impact of fluctuations in the variables of PMA, PMDN, employment, and exports of the manufacturing industry on economic growth, the VECM model analysis was used after the cointegration test was carried out and it was found that there was cointegration between the variables in the model. The stages of analysis are as follows:

\section{1) Data Stationarity Test (Unit Root Test)}

The data stationarity test was carried out by unit root test for each variable. The variables in the model include DPDBX, PMA, PMDN, employment, and manufacturing industry exports. Unit root test using Augmented-Dickey Fuller (ADF) test. The hypothesis used is $\mathrm{H}_{0}: \beta=0$ (data is not stationary); $\mathrm{H}_{1}: \beta<0$ (stationary data). The test rule: if statistical ADF < critical ADF, then accept $\mathrm{H}_{0}$ (non-stationary data), if statistical $\mathrm{ADF}>$ critical $\mathrm{ADF}$, then reject $\mathrm{H}_{0}$ and accept $\mathrm{H}_{1}$ (stationary data).

\section{2) Cointegration Test}

After conducting the data stationarity test, a cointegration test was conducted to see whether the data had a long-term relationship or not. If the cointegration test results show that there is no cointegration between variables, the model used is VAR in difference. On the other hand, if there is cointegration between variables, the model used is VECM. To determine the cointegration relationship, statistical tests were carried out, namely trace statistics $\left(\lambda_{\text {trace }}(\tau)\right)$ and maximum eigenvalue test $\left(\lambda_{\max }\right)$ with the following equation:

$$
\begin{aligned}
& \lambda_{\text {trace }}(r)=-T_{i=r+1}^{n} \ln \left(1-\lambda_{i}\right) \ldots \ldots \ldots \ldots \text { (8) } \\
& \lambda_{\text {max }}(r, r+1)=-T \ln \left(1-\lambda_{r+1}\right) \ldots \ldots \ldots \text { (9) } \\
& \text { Information: } \\
& \mathrm{T} \quad=\text { Number of observations } \\
& \mathrm{Ai} \quad=\text { Estimated value of the i-order eigenvalue } \\
& \quad \text { obtained from the } \Pi \text { matrix } \\
& \mathrm{r} \quad=\text { Power indicating the number of } \\
& \quad \text { cointegration vectors. }
\end{aligned}
$$

The assumption used if the value of $\lambda_{\text {trace }}<\lambda_{\text {table }}$ then accept $H_{0}$ i.e. the number of cointegrated vectors $=r$ is the alternative number of cointegrated vectors $r+1$. Decision making can be seen based on the value of the results of the trace statistic or max - Eigenvalue statistic. The hypothesis used in the cointegration analysis is $\mathrm{H}_{0}=$ non-cointegrated or there is no longterm relationship between the variables analyzed and $\mathrm{H}_{1}=$ cointegrated or there is a long-term relationship between the variables analyzed. If the trace statistic value > critical value, then reject $\mathrm{H}_{0}$ or accept $\mathrm{H}_{1}$ that is there is a cointegration relationship. If the max value - Eigenvalue statistic > critical value, then the null hypothesis is rejected or there is a cointegration relationship between variables.

\section{3) VECM Estimation}

Cointegration test shows that the variables in the model have a cointegration relationship so that the model used is the VECM model. The VECM equation in vector form for economic growth related to manufacturing industry exports and investment in this study is: 


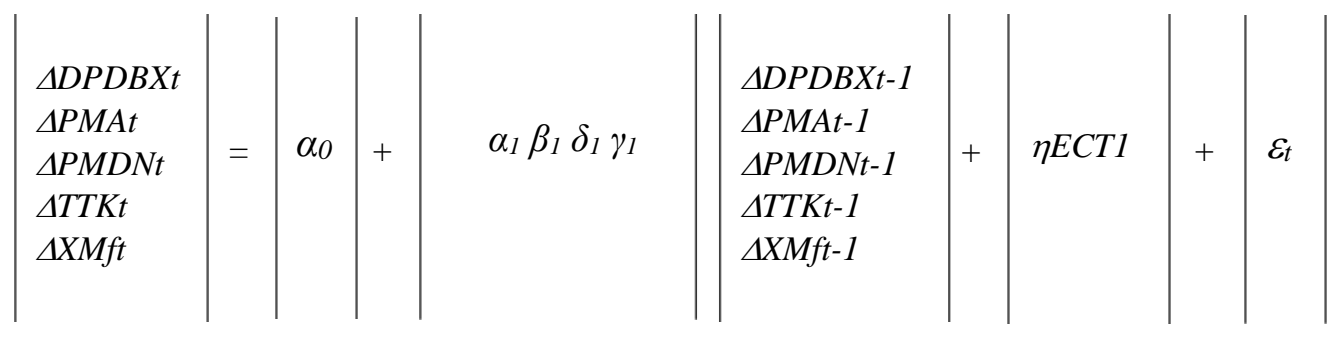

\section{RESULTS AND DISCUSSION}

\subsection{Results}

\section{1) Data Stationarity Test}

The data used in this study is data in the form of normal logarithms. Stationarity testing was carried out using the Augmented Dickey Fuller Unit Root Test (ADF) technique. The test is carried out with the intercept and trend model with level data and then proceed with the first difference level. The results of the stationarity test of the data are summarized in Table 1.

Table 1. Data stationarity test

\begin{tabular}{|c|c|c|}
\hline \multicolumn{3}{|c|}{ Augmented Dickey Fuller Unit Root Test (ADF) } \\
\hline \multirow{2}{*}{ Variable } & \multicolumn{2}{|c|}{ Intercept and Trend } \\
\hline & Level & First Difference \\
\hline $\begin{array}{l}\text { Value of GDP without Export } \\
\text { (LOGDPDBX) }\end{array}$ & $-2.129765[0.5232]$ & $-4.503868[0.0024]$ \\
\hline Foreign Investment (LOGPMA) & $-8.015371[0.0000]$ & $-10.58294 \quad[0.0000]$ \\
\hline Domestic Investment (LOGPMDN) & $-1.901563[0.6469]$ & $-10.09066[0.0000]$ \\
\hline Employment (LOGTTK) & $-1.925811[0.6343]$ & $-10.50728 \quad[0.0000]$ \\
\hline $\begin{array}{l}\text { Manufacturing Industry Export } \\
\text { (LOGXMF) }\end{array}$ & $-2.088076[0.5465]$ & $-8.353142[0.0000]$ \\
\hline
\end{tabular}

\section{2) Optimum Lag Test}

The purpose of determining the optimum lag is to eliminate the problem of autocorrelation in the VAR/VECM system. The determination of the lag length uses the Likehood Ratio (LR), Final Prediction Error (FPE) criteria, Akaike Information Criterion (AIC), Shwarz Information Criterion (SC), and Hannan-Quin Criterion (HQ). For the Final Prediction Error (FPE), Akaike Information Criterion (AIC), Shwarz Information Criterion (SC), and Hannan-Quin Criterion (HQ) criteria, each requires the smallest value. For the Likelihood Ratio (LR) criteria, the largest value was chosen. The results of the optimal lag length test are shown in Table 2. 
Alfred Leonard et al Int J Sci Res Sci Eng Technol, September-October-2021, 8 (5) : 92-101

Table 2 Optimal lag criteria for GDP, investment, employment, and exports

\begin{tabular}{ccccccc}
\hline \hline Lag & LogL & LR & FPE & AIC & SC & HQ \\
\hline \hline 0 & 49.40019 & NA & $1.08 \mathrm{e}-09$ & -0.777985 & $-0.605146^{*}$ & -0.707893 \\
1 & 141.3540 & 170.4098 & $4.94 \mathrm{e}-10$ & -1.566128 & -0.183417 & -1.005388 \\
2 & 213.8149 & 124.9785 & $3.24 \mathrm{e}-10$ & -1.996604 & 0.595979 & -0.945217 \\
3 & 294.0067 & $128.0125^{*}$ & $1.88 \mathrm{e}-10^{*}$ & $-2.568929^{*}$ & 1.233525 & $-1.026895^{*}$ \\
\hline \hline
\end{tabular}

Description: * shows the value selected by the criteria

\section{3) Cointegration Test}

Cointegration test uses the Johansen test approach. Johansen's cointegration test results on the research variables can be seen in Table 3. The table shows that there are 2 (two) equations that can explain the cointegration relationship of the variables in the model or it can be said that these variables have a long-term relationship.

Table 3 Johansen cointegration test of GDP, investment, employment, and exports

\begin{tabular}{ccccc}
\hline \hline \multicolumn{5}{l}{ Unrestricted Cointegration Rank Test (Trace) } \\
\hline \hline $\begin{array}{c}\text { Hypothesized } \\
\text { No. of CE(s) }\end{array}$ & Eigenvalue & $\begin{array}{c}\text { Trace } \\
\text { Statistic }\end{array}$ & $\begin{array}{c}0.05 \\
\text { Critical Value }\end{array}$ & Prob. $^{* *}$ \\
\hline \hline None $^{*}$ & 0.271471 & 87.66093 & 69.81889 & 0.0010 \\
At most $1{ }^{*}$ & 0.225872 & 53.13763 & 47.85613 & 0.0147 \\
At most 2 & 0.112505 & 25.23166 & 29.79707 & 0.1533 \\
At most 3 & 0.091771 & 12.22228 & 15.49471 & 0.1466 \\
At most 4 & 0.015747 & 1.730106 & 3.841466 & 0.1884 \\
\hline \hline
\end{tabular}

Trace test indicates 2 cointegrating eqn(s) at the 0.05 level

* denotes rejection of the hypothesis at the 0.05 level

${ }^{* *}$ MacKinnon-Haug-Michelis (1999) p-values

\begin{tabular}{ccccc}
\hline \hline \multicolumn{6}{l}{ Unrestricted Cointegration Rank Test (Maximum } & \\
\hline \hline $\begin{array}{c}\text { Hypothesized } \\
\text { No. of CE(s) }\end{array}$ & Eigenvalue & $\begin{array}{c}\text { Max-Eigen } \\
\text { Statistic }\end{array}$ & $\begin{array}{c}0.05 \\
\text { Critical Value }\end{array}$ & Prob. $^{* *}$ \\
\hline \hline None ${ }^{*}$ & 0.271471 & 34.52330 & 33.87687 & 0.0418 \\
At most 1 & 0.225872 & 27.90596 & 27.58434 & 0.0455 \\
At most 2 & 0.112505 & 13.00939 & 21.13162 & 0.4514 \\
At most 3 & 0.091771 & 10.49217 & 14.26460 & 0.1816 \\
At most 4 & 0.015747 & 1.730106 & 3.841466 & 0.1884 \\
\hline \hline
\end{tabular}

Max-eigenvalue test indicates 2 cointegrating eqn(s) at the 0.05 level 
* denotes rejection of the hypothesis at the 0.05 level

${ }^{* *}$ MacKinnon-Haug-Michelis (1999) p-values

\section{4) Estimation of Vector Error Correction Model (VECM)}

Vector Error Correction Model (VECM) is an restricted VAR model that is used for variables that are not stationary but have the potential to be cointegrated. The results of the $t$-statistical values from the VECM equation model of GDP, investment, employment, and exports that affect economic growth through increasing productivity, will be compared with the $t$-table value. If the $t$-statistic value is greater than the $\mathrm{t}$-table value, it can be said that the variable has a significant effect. The estimation results for the cointegration equation one are presented in the following equation (10).

DPDBX $=11.8776-0.1623 \mathrm{PMA}^{* * *}+0.3088$

$\mathrm{PMDN}^{* * *}-0.0425 \mathrm{TKK}+0.1492 \mathrm{XMF}^{* * *}$

Description: $^{* * *}=$ significant at $1 \%$ level

\subsection{Discussion}

Equation (10) above shows that there is a long-term relationship between foreign investment, domestic investment, employment, and manufacturing exports and GDP. The variables of foreign investment, domestic investment, and exports of the manufacturing industry have a statistically significant relationship at the $1 \%$ confidence level. While the labor absorption variable is not significant. In terms of the direction of the relationship with GDP, the variables of foreign investment and employment are both not in line with expectations, which are negative. In addition to the relationship of variables that match expectations with GDP are domestic investment and exports of the manufacturing industry. In other words, these two variables are positive.

A $1 \%$ increase in foreign investment (FDI) will reduce GDP by $0.16 \%$, whereas a $1 \%$ increase in domestic investment (DI) will increase GDP by $0.31 \%$. The relationship between employment and GDP is not as expected, nor is it significant. A $1 \%$ increase in manufacturing exports would increase GDP by $0.15 \%$. Unlike the results of the analysis of other researchers, the results of this study found that FDI had a negative effect on GDP. The results of the analysis of Okada and Samreth (2014) using data from 130 countries found that foreign investment can have a positive or negative impact on economic growth. In conditions of severe corruption, foreign investment has a positive impact on increasing economic growth. On the other hand, in conditions of corruption below a certain threshold, foreign investment has a negative impact on economic growth. Another analysis result as stated by Tabor (2015) that the Indonesian economy is experiencing growth constraints, one of which is caused by the level of capital investment which remains high but the economic return is low. Relatively high economic returns occur on passive investments in financial assets rather than in physical assets.

The positive effect of domestic investment (DI) on GDP shows that an increase in DI has an effect on increasing economic growth. The results of this analysis are in line with You and Solomon's (2015) analysis that the Chinese economy experienced a large expansion of foreign investment, but China's domestic economic growth continued to rely on the accumulation of domestic investment and not on foreign investment. This shows that domestic investment (DI) plays a major role in encouraging domestic economic growth.

Indonesia is known to have large labor resources as the main production factor in national production. However, the estimation results show that employment has a negative and insignificant effect on GDP. This means that an increase in employment leads to a decrease in GDP. The labor absorption data used in the analysis of this research is the labor 
absorbed in foreign investment (FDI) and domestic investment (DI).

The progress of employment as shown in the previous section of the graph shows that labor absorption conditions are unstable from time to time and tend to decline. This condition is contrary to the development of GDP which continues to increase from time to time. Absorption of labor that continues to change from time to time and decreases indicating available jobs that can absorb labor may not be available. Tadjoeddin (2014) stated that the policy set by the government related to labor is the target of reducing unemployment by $5-6 \%$ by 2014 . However, decent work is not available. This unavailability of employment has a negative effect on economic growth. Herman's analysis (2011) show that the small capacity to create jobs has an impact on guaranteeing economic growth.

The results of the analysis of manufacturing industry exports to GDP show that manufacturing industry exports have a positive effect on Indonesia's economic growth in the long term. This means that an increase in manufacturing exports has an effect on increasing economic growth. The results of this analysis are in line with the analysis of Nguyen (2016) that exports have a positive and significant impact on economic growth. The analysis by Jongwanich (2020) is even clearer that manufacturing industry exports through export diversification have a positive and significant effect on increasing economic growth.

The negative effect of FDI on Indonesia's economic growth in this study resulted from the analysis of national level data. These findings are in line with the findings of Okada and Samreth (2014) who used data from 130 countries. According to Okada and Samreth, the cause of the negative influence of FDI on growth is caused by corruption conditions below a certain threshold. In Indonesia, the reason is according to the findings of Tabor (2015) that the economic return from capital investment is low. Relatively high economic returns occur in passive investments in financial assets and not in physical (real) assets. Khaliq and Noy (2007) found that the negative effect of FDI on growth occurred at the sectoral level analysis. While the analysis at the national level (aggregate), FDI has a positive effect on growth. Khaliq and Noy's findings contradict the findings of this study.

Indonesia has an excess number of workers, but the results of the analysis in this study also found a negative effect of labor absorption on economic growth. The reason stated is the lack of adequate employment opportunities.

\section{CONCLUSION}

Based on the results and discussion, it can be concluded that there is a long-term relationship between foreign investment, domestic investment, employment, and manufacturing exports with GDP. Foreign investment, domestic investment, and exports of the manufacturing industry have a statistically significant relationship. While the absorption of labor is not significant. Domestic investment and manufacturing exports have a positive relationship to GDP. On the other hand, foreign investment and employment have a negative relationship.

An indication of the negative influence of FDI in Indonesia is due to the low rate of economic return. Meanwhile, the negative effect of labor absorption is indicated by the unavailability of adequate employment opportunities.

\section{REFERENCES}

[1]. Aftab, A. and Parikh, D., 2018. Comparative analysis of impact of foreign direct investment, exports and employment on growth of manufacturing industries in India. Asian Economic and Financial Review, 8(9), pp.11961210. 
[2]. Agrawal P. 2015. The Role of Exports in India's Economic Growth. The Journal of International Trade \& Economic Development. 24(6):835-859.

[3]. Bank Indonesia. 2020. Laporan Tahunan Bank Indonesia. Bank Sentral Indonesia, Jakarta.

[4]. Djulius, H., Wongyu, C., Juanim, J. and Santy, R.D., 2019. Nexus of Foreign Direct Investment, Domestic Investment, and Manufacturing Industry Value Added in Indonesia. Signifikan: Jurnal Ilmu Ekonomi, 8(1), pp.1-8.

[5]. Dreger, C. and Herzer, D., 2013. A further examination of the export-led growth hypothesis. Empirical Economics, 45(1), pp.39-60.

[6]. Faizah, I., Fasa, M. I., Suharto, S., Rahmanto, D. N. A., \& Athief, F. H. N. 2019. Determinants of Domestic Direct Investment in Indonesia: Islamic Economic Approach. JEJAK: Jurnal Ekonomi dan Kebijakan, 12(2), 282-297.

[7]. Ferreira GFe, and Harrison RW. 2012. From Coffe Beans to Microchips: Export Diversification and Economic Growth in Costa Rica. Journal of Agricultural and Applied Economics. 44(4):517531.

[8]. Herman, E., 2011. The impact of economic growth process on employment in European Union countries. The Romanian Economic Journal, 14(42), pp.47-67.

[9]. Hossain M, and Karunaratne ND. 2004. Export and Economic Growth in Bangladesh: Has Manufacturing Exports Become a New Engine of Export-Led Growth? The International Trade Journal. 18(4):303-334.

[10]. Jongwanich, J., 2020. Export diversification, margins and economic growth at industrial level: Evidence from Thailand. The World Economy, 43(10), pp.2674-2722.

[11]. Khaliq, A. and Noy, I., 2007. Foreign direct investment and economic growth: Empirical evidence from sectoral data in Indonesia. Journal of Economic Literature, 45(1), pp.313-325.

[12]. Leichenko, R. M. 2000. Exports, employment, and production: A causal assessment of US states and regions. Economic Geography, 76(4), 303-325.
[13]. Lindblad, J. T. 2015. Foreign direct investment in Indonesia: Fifty years of discourse. Bulletin of Indonesian Economic Studies, 51(2), 217-237.

[14]. Mankiw NG. 2006. Principles of Macroeconomics. Cengage Learning.

[15]. Nguyen TH. 2016. Impact of Export on Economic Growth in Vietnam: Empirical Research and Recommendations. International Business and Management. 13(3):45-52.

[16]. Okada, K. and Samreth, S., 2014. How does corruption influence the effect of foreign direct investment on economic growth? Global Economic Review, 43(3), pp.207-220.

[17]. Tabor, S. R. (2015). Constraints to Indonesia's economic growth. ADB Papers on Indonesia. No. 10.

[18]. Tadjoeddin, M. Z. 2014. Decent work: On the quality of employment in Indonesia. Asian Journal of Social Science, 42(1-2), 9-44.

[19]. Thangavelu, S.M. and Owyong, D.T., 2003. The impact of export growth and scale economies on productivity in Singapore's manufacturing industries. Journal of Economic Studies.

[20]. Van der Eng, P., 2010. The sources of long-term economic growth in Indonesia, 1880-2008. Explorations in Economic History, 47(3), pp.294309.

[21]. You K, Solomon OH. 2015. China's outward foreign direct investment and domestic investment: An industrial level analysis. China Economic Review. pp.249-260.

\section{Cite this article as :}

Nadhia S Alfred Leonard, Tanti Novianti, Sri Mulatsih, "Analysis of the Impact of Exports and Investment on Indonesian Economic Growth", International Journal of Scientific Research in Science, Engineering and Technology (IJSRSET), Online ISSN : 2394-4099, Print ISSN : 2395-1990, Volume 8 Issue 5, pp. 92-101, September-October 2021. Available at doi $\quad$ : https://doi.org/10.32628/IJSRSET21853

Journal URL : https://ijsrset.com/IJSRSET21853 